\title{
Occurrence of Dermatitis in Rats Fed a Cholesterol Diet Containing Field Horsetail (Equisetum arvense L.)
}

\author{
Hideo MaEda, Kana MiYamoto and Toshiaki SANO ${ }^{1}$ \\ Faculty of Health and Living Sciences, Naruto University of Education, Naruto 772, Japan \\ ${ }^{1}$ First Department of Pathology, School of Medicine, The University of Tokushima, \\ Tokushima 770, Japan
}

(Received April 30, 1997)

\begin{abstract}
Summary The effects of dietary field horsetail (Equisetum arvense L.) powder on lipid components were studied in rats fed a $20 \%$ casein diet with or without cholesterol $(0.5 \%$ cholesterol and $0.15 \%$ sodium cholate) for 14 days. The ingestion of $0.4 \%$ or $4 \%$ Equisetum arvense L. powder did not influence food intake or growth. However, a cholesterol diet with Equisetum arvense L. at $4 \%$ caused dermatitis at the neck, head and back in about $20-65 \%$ of the rats. This dermatitis was reversed when the diet was changed to commercial pellets. There were no apparent effects on serum or liver lipids in the rats fed Equisetum arvense L. irrespective of dietary cholesterol. Serum IgE levels measured by enzyme-linked immunoassay revealed that the induction of $\operatorname{IgE}$ may not necessarily be involved in the dermatitis caused by the intake of Equisetum arvense L. These results suggest that the ingestion of large amounts of Equisetum arvense $\mathrm{L}$. as cooking material is not recommended for those with a cholesterol-rich diet.
\end{abstract}

Key Words cholesterol, dermatitis, Equisetum arvense L., IgE, lipids

Tea is traditionally and widely consumed as a beverage in the Orient. Green tea leaves contain large amounts of polyphenols, such as catechins, and black tea leaves contain oxidized products of catechins, such as theaflavins and thearubigin. These catechins and oxidized catechin products exhibit antioxidative activity $(1,2)$ and have a plasma lipid lowering effect (3-7). Equisetum arvense L. is used not only for decoction as tea but also in cooking materials. This plant has been included in several European and Japanese pharmacopoeias. However, the specific modes of action of this plant are not yet clear. By contrast, it was reported that Equisetum arvense L. and its basidium have caused fatalities in farm stock as contaiminants of hay (8). Alkaloids (9) and antithiamine action $(10,11)$ are thought to be one of the factors for its toxicity. However, few studies have been published on the biological activity, such as lipid metabolism, of this plant in experimental animals.

In this study, we investigated the effects of the intake of Equisetum arvense L. on lipid content in the serum and liver of rats fed a cholesterol diet, and found 
that Equisetum arvense L. induced dermatitis.

\section{MATERIALS AND METHODS}

Materials. A commercial dry powder of Equisetum arvense L. (whole heat air-dried plants) was obtained from Kisawa Village in Tokushima Prefecture, Japan. It was stored at $-30^{\circ} \mathrm{C}$ and used within 6 months after harvesting.

Animals. Male Sprague-Dawley rats (4 weeks old) were obtained from Clea, Japan (Tokyo, Japan). Rats were fed commercial pellets (Oriental Yeast, Japan) ad libitum for 7 days as they adjusted to the new environment and were assigned to groups. Two experiments were conducted using six different diets as shown in Table 1. The basal experimental diet used was a $20 \mathrm{C}$ diet (milk casein, $20 \%$; sucrose, $10 \%$; corn starch, $54.5 \%$; mineral mixture, $4 \%$; vitamin mixture, $1 \%$; choline bitartrate, $0.2 \%$; DL-methionine, $0.3 \%$ ). In experiment 1 , rats were given free access to three diets $(20 \mathrm{C}, 20 \mathrm{C}+0.4 \mathrm{E}$, and $20 \mathrm{C}+4 \mathrm{E})$ with or without Equisetum arvense L. at $0.4 \%$ or $4 \%$ for 14 days. In experiment 2 , rats were given free access to four diets $(20 \mathrm{C}, 20 \mathrm{CCS}, 20 \mathrm{CCS}+0.4 \mathrm{E}$, and $20 \mathrm{CCS}+4 \mathrm{E})$ with or without Equisetum arvense $\mathrm{L}$. at $0.4 \%$ or $4 \%$ containing cholesterol $(0.5 \%$ cholesterol and $0.15 \%$ sodium cholate) for 14 days. The experimental diet $(20 \mathrm{CCS}+4 \mathrm{E})$ of one rat with severe dermatitis was changed to commercial pellets on the 14th day, and was given for an additional 8 weeks. Rats were deprived of food for $6 \mathrm{~h}$ before decapitation under anesthetization with diethyl ether.

Table 1. Composition of experimental diets.

\begin{tabular}{|c|c|c|c|c|c|c|}
\hline \multirow{2}{*}{ Ingredient } & \multicolumn{3}{|c|}{ Experiment 1} & \multicolumn{3}{|c|}{ Experiment 2} \\
\hline & $20 \mathrm{C}$ & $20 \mathrm{C}+0.4 \mathrm{E}$ & $20 \mathrm{C}+4 \mathrm{E}$ & $20 \mathrm{CCS}$ & $\mathrm{CCS}+0.4 \mathrm{E}$ & $20 \mathrm{CCS}+4 \mathrm{E}$ \\
\hline & \multicolumn{6}{|c|}{$(\mathrm{g} / \mathrm{kg})$} \\
\hline Milk casein & 200 & 200 & 200 & 200 & 200 & 200 \\
\hline Sucrose & 100 & 100 & 100 & 100 & 100 & 100 \\
\hline Corn starch & 545 & 541 & 505 & 538.5 & 534.5 & 498.5 \\
\hline Soybean oil ${ }^{1}$ & 100 & 100 & 100 & 100 & 100 & 100 \\
\hline Mineral $\operatorname{mix}^{2}$ & 40 & 40 & 40 & 40 & 40 & 40 \\
\hline Vitamin $\operatorname{mix}^{3}$ & 10 & 10 & 10 & 10 & 10 & 10 \\
\hline Choline bitartrate & 2 & 2 & 2 & 2 & 2 & 2 \\
\hline DL-Methionine & 3 & 3 & 3 & 3 & 3 & 3 \\
\hline Cholesterol & - & - & - & 5 & 5 & 5 \\
\hline Sodium cholate & - & - & - & 1.5 & 1.5 & 1.5 \\
\hline Equisetum arvense $\mathrm{L}$. & - & 4 & 40 & - & 4 & 40 \\
\hline
\end{tabular}

${ }^{1}$ Soybean oil was supplemented with $14 \mathrm{mg}$ of tert-butylhydroquinone per $\mathrm{kg}$ diet.

${ }^{2}$ Modified AIN-93 mineral mixtures (AIN-93G) and ${ }^{3}$ modified AIN-93 vitamin mixtures (AIN-93-VX) for rats were purchased from Oriental Yeast, Tokyo, Japan. 
The livers were immediately removed, frozen in liquid nitrogen, and stored at $-30^{\circ} \mathrm{C}$ pending lipid, glycogen, and protein analyses. Feces were collected for 2 days between the 11th and 13th day of the experimental periods, and lyophilized feces were stored at $-50^{\circ} \mathrm{C}$ until lipid analysis. Animals were cared for in accordance with the guidelines established by the Japanese Society of Nutrition and Food Science.

Enzyme assay. The livers of rats from experiment 2 were immediately removed and homogenized in a Teflon homogenizer with 10 volumes of $0.25 \mathrm{M}$ sucrose solution containing $5 \mathrm{~mm}$ Tris- $\mathrm{HCl}$ buffer $(\mathrm{pH} 7.4)$ and $0.1 \mathrm{~mm}$ EDTA. The homogenate was centrifuged at $8,000 \times g$ for $20 \mathrm{~min}$, and the supernatant was further centrifuged at $10,500 \times g$ for $60 \mathrm{~min}$. The resulting supernatant was used as the source of glucose-6-phosphate dehydrogenase [EC 1.1.1.49], and malic enzyme [EC 1.1.1.40]. The activities of these enzymes were determined photometrically as previously described (12). Enzyme unit (1 kat) was defined as the formation of 1 mol of NADPH per second per mg of cytosol protein.

Lipid analysis. Hepatic and fecal lipids were extracted and purified according to the method of Folch et al (13). Hepatic triglyceride, phospholipid and cholesterol levels were determined colorimetrically as previously described (12). Serum triglyceride, phospholipid and cholesterol levels were determined using an enzymatic assay kit (Wako Pure Chemicals, Osaka, Japan). The total lipids of the feces were determined by gravimetry.

Glycogen analysis. Livers were homogenized with four volumes of distilled water at $4{ }^{\circ} \mathrm{C}$. Glycogen in the liver homogenate was hydrolyzed in $2.25 \mathrm{~N} \mathrm{H}_{2} \mathrm{SO}_{4}$ for $2 \mathrm{~h}$ in a boiling water bath; the sample was then neutralized with ten volumes of $0.4 \mathrm{M}$ potassium phosphate buffer ( $\mathrm{pH} 7.4$ ) (14). After centrifugation of the acid hydrolysate at $16,000 \times g$ for $20 \mathrm{~min}$, an aliquot of the clear supernatant was tested for glucose with an enzymatic assay kit (Wako Pure Chemicals). Glycogen content was calculated by subtracting the glucose content with acid hydrolysate from the glucose content without acid hydrolysis.

Quantitative analysis of rat serum IgE. IgE levels were measured by enzyme-linked immunoassay using two different monoclonal antibodies against murine anti-rat IgE (Yamasa, Tokyo, Japan). Polyvinyl chloride microtiter plates were coated with $50 \mu \mathrm{l}$ of anti-rat IgE monoclonal antibody (IgG2bk) at a concentration of $10 \mu \mathrm{g} / \mathrm{mL}$ in $10 \mathrm{~mm}$ sodium phosphate buffer saline solution (PBS, $\mathrm{pH}$ 7.4) and were saturated with $1 \%$ bovine serum albumin. Rat myeloma IgE (Zymed Laboratories, San Francisco, CA, USA) as the standard and the unknown serum sample diluted in the saturated solution were incubated in wells for $2 \mathrm{~h}$ at room temperature. After washing with PBS buffer, horseradish peroxidaseconjugated anti-rat IgE monoclonal antibody (IgG1 $k$ ) as a second antibody at a concentration of $5 \mu \mathrm{g} / \mathrm{mL}$ was added and allowed to stand for $2 \mathrm{~h}$. After washing with PBS buffer, $10 \mathrm{mM} o$-phenylenediamine and $0.1 \% \mathrm{H}_{2} \mathrm{O}_{2}$ in $100 \mathrm{~mm}$ citrate buffer ( $\mathrm{pH} 5.3$ ) were added and the reaction was stopped by the addition of $2 \mathrm{~N}$ $\mathrm{H}_{2} \mathrm{SO}_{4}$. The developed color was determined at $490 \mathrm{~nm}$ with a microplate reader 
(model 450, Bio-Rad Laboratories, Richmond, CA, USA).

Histological study. Skin tissues of the neck were fixed in $10 \%$ formaldehyde solution, embedded in paraffin, sliced into cross sections $4 \mu \mathrm{m}$ in thickness and then stained by a hematoxylin-eosin solution.

Other measurements. Protein concentration of the liver homogenate was determined by biuret reaction (15) after precipitation by $10 \%$ trichloroacetic acid and delipidation by diethyl ether; cytosol protein was determined by the method of Lowry et al (16). A statistical analysis was performed by analysis of variance (ANOVA) coupled with Duncan's multiple range test (17), and significant differences in the mean were inspected at $p<0.05$.

\section{RESULTS}

Effect of growth parameter and tissue weight

Tables 2 and 3 show the effects of Equisetum arvense L. on weight gain, food intake and tissue weight with or without a cholesterol diet, respectively. The addition of Equisetum arvense L. at $0.4 \%$ or $4 \%$ had no significant effect on weight gain, food intake, food efficiency or tissue weight, although the liver tended to enlarge in rats given a cholesterol diet as compared to those not given a cholesterol diet. The addition of $4 \%$ Equisetum arvense L. with or without a cholesterol diet increased the volume of feces.

\section{Histological findings}

On the 9-12th day after commencing the cholesterol diet with 4\% Equisetum arvense L., four of six rats lost hair and dermatitis was observed on the neck, head, nose and back as shown in Fig. 1. By light microscopy, dense infiltration of neutrophils and lymphocytes was observed in the dermis and subcutaneous tissue. At the center of the eruption, the dermis was ulcerated. The number of mast cells

Table 2. Effects of Equisetum arvense $\mathrm{L}$. on growth parameter and tissue weight (Experiment 1).

\begin{tabular}{|c|c|c|c|}
\hline & $20 \mathrm{C}$ & $20 \mathrm{C}+0.4 \mathrm{E}$ & $20 \mathrm{C}+4 \mathrm{E}$ \\
\hline Initial body weight (g) & $151 \pm 7$ & $150 \pm 7$ & $154 \pm 8$ \\
\hline Final body weight (g) & $265 \pm 19$ & $264 \pm 16$ & $259 \pm 13$ \\
\hline Weight gain (g/14 days) & $114 \pm 13$ & $113 \pm 10$ & $106 \pm 10$ \\
\hline Food intake (g/14 days) & $293 \pm 34$ & $300 \pm 23$ & $316 \pm 15$ \\
\hline Food efficiency ${ }^{1}$ & $0.39 \pm 0.04$ & $0.38 \pm 0.01$ & $0.34 \pm 0.04$ \\
\hline Liver weight (g) & $11.4 \pm 1.4$ & $10.7 \pm 1.4$ & $10.7 \pm 0.6$ \\
\hline Kidney weight (g) & $2.19 \pm 0.23$ & $2.34 \pm 0.19$ & $2.34 \pm 0.11$ \\
\hline Feces weight (g/2 days) & $1.07 \pm 0.01^{\mathrm{a}}$ & $1.15 \pm 0.19^{\mathrm{a}}$ & $1.80 \pm 0.32^{\mathrm{b}}$ \\
\hline
\end{tabular}

Values ( $\mathrm{M} \pm \mathrm{SD}$ of five rats) in the same line not sharing a common superscript letter are significantly different at $p<0.05 .{ }^{1}$ Body weight gain $(\mathrm{g}) /$ food intake $(\mathrm{g})$. 
Table 3. Effects of Equisetum arvense L. on growth parameter and tissue weight of rats fed a cholesterol diet (Experiment 2).

\begin{tabular}{lcccc}
\hline & $20 \mathrm{C}$ & $20 \mathrm{CCS}$ & 20CCS $+0.4 \mathrm{E}$ & $20 \mathrm{CCS}+4 \mathrm{E}$ \\
\hline Initial body weight $(\mathrm{g})$ & $172 \pm 11$ & $171 \pm 12$ & $171 \pm 13$ & $176 \pm 20$ \\
Final body weight $(\mathrm{g})$ & $272 \pm 23$ & $269 \pm 14$ & $269 \pm 21$ & $272 \pm 26$ \\
Weight gain (g/14 days) & $100 \pm 13$ & $98 \pm 8$ & $98 \pm 10$ & $96 \pm 7$ \\
Food intake (g/14 days) & $290 \pm 27$ & $295 \pm 28$ & $303 \pm 40$ & $298 \pm 23$ \\
Food efficiency & $0.34 \pm 0.02$ & $0.33 \pm 0.01$ & $0.33 \pm 0.02$ & $0.32 \pm 0.04$ \\
Liver weight (g) & $11.7 \pm 1.9$ & $13.5 \pm 2.0$ & $14.0 \pm 1.6$ & $14.1 \pm 1.4$ \\
Kidney weight (g) & $2.21 \pm 0.21$ & $2.24 \pm 0.27$ & $2.30 \pm 0.20$ & $2.25 \pm 0.16$ \\
Feces weight (g/2 days) & $0.94 \pm 0.13^{\mathrm{a}}$ & $1.25 \pm 0.07^{\mathrm{a}}$ & $1.19 \pm 0.30^{\mathrm{a}}$ & $2.06 \pm 0.36^{\mathrm{b}}$ \\
\hline
\end{tabular}

Values ( $\mathrm{M} \pm \mathrm{SD}$ of five rats) in the same line not sharing a common superscript letter are significantly different at $p<0.05 .{ }^{1}$ Body weight gain $(\mathrm{g}) /$ food intake $(\mathrm{g})$.

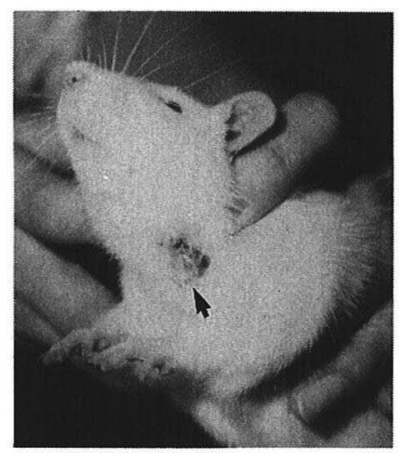

A

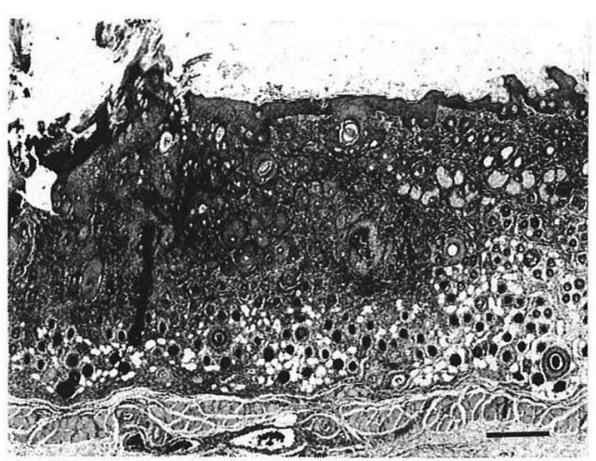

B

Fig. 1. Dermatitis (A) and light microscopy (B) of rat induced by $4 \%$ Equisetum arvense $\mathrm{L}$. with cholesterol on the 13th day. The neck tissue was stained with hematoxylin-eosin. Arrow in A indicates the location of dermatitis and the short bar in B represents $333 \mu \mathrm{m}$.

was moderately increased, but no granuloma was seen. Thus, nonspecific inflammatory lesion of the skin was diagnosed. At the end of the 2-week experimental period, the rat most seriously afflicted with dermatitis was excluded from the serum and hepatic analyses and its experimental diet $(20 \mathrm{CCS}+4 \mathrm{E})$ changed to commercial pellets. The dermatitis of this rat gradually alleviated over the next two weeks, and the animal had completely recovered by the sixth week (data not shown).

\section{Glycogen, protein and lipids}

Table 4 shows the effects of dietary Equisetum arvense L. without the addition of cholesterol on the content of hepatic glycogen and protein, and serum, hepatic and excreted lipids. There were no significant differences in hepatic glycogen and 
Table 4. Effects of Equisetum arvense L. on the content of glycogen, protein and lipids (Experiment 1).

\begin{tabular}{lccc}
\hline & $20 \mathrm{C}$ & $20 \mathrm{C}+0.4 \mathrm{E}$ & $20 \mathrm{C}+4 \mathrm{E}$ \\
\hline Liver (mg/g liver) & & & \\
$\quad$ Glycogen & $30.9 \pm 7.0$ & $24.0 \pm 11.9$ & $28.4 \pm 3.3$ \\
$\quad$ Protein & $137 \pm 6$ & $142 \pm 5$ & $140 \pm 6$ \\
Liver lipids ( $\mu \mathrm{mol} / \mathrm{g}$ liver) & & & \\
$\quad$ Triglyceride & $26.2 \pm 6.2$ & $23.6 \pm 3.2$ & $26.6 \pm 5.4$ \\
$\quad$ Phospholipid & $38.9 \pm 1.4$ & $38.1 \pm 2.6$ & $36.2 \pm 1.5$ \\
$\quad$ Cholesterol & $9.03 \pm 0.47$ & $8.07 \pm 0.59$ & $8.30 \pm 0.70$ \\
Serum lipids (mmol/L) & & & \\
$\quad$ Triglyceride & $1.32 \pm 0.55$ & $1.32 \pm 0.41$ & $1.31 \pm 0.09$ \\
$\quad$ Phospholipid & $1.76 \pm 0.19$ & $1.64 \pm 0.13$ & $1.65 \pm 0.06$ \\
$\quad$ Cholesterol & $2.25 \pm 0.26$ & $2.15 \pm 0.18$ & $2.22 \pm 0.21$ \\
Feces & & & \\
$\quad$ Total lipids (mg/g) & $219 \pm 21^{\mathrm{a}, \mathrm{b}}$ & $230 \pm 29^{\mathrm{a}}$ & $174 \pm 31^{\mathrm{b}}$ \\
$\quad$ Total lipids (mg/2 days) & $233 \pm 31$ & $264 \pm 52$ & $321 \pm 118$ \\
\hline
\end{tabular}

Values $(\mathrm{M} \pm \mathrm{SD}$ of five rats) in the same line not sharing a common superscript letter are significantly different at $p<0.05$.

proteins, serum and hepatic lipid components. In addition, there was no significant effect of Equisetum arvense L. on excreted lipids per total feces for 2 days, although total lipids per gram weight of feces was lower in the diet with $4 \%$ Equisetum arvense L. than in the diet with $0.4 \%$ Equisetum arvense $\mathrm{L}$.

Table 5 shows the effects of dietary Equisetum arvense L. with a cholesterol diet on the content of hepatic glycogen and protein, and serum, hepatic and excreted lipids. When rats were fed a cholesterol diet, hepatic triglyceride and cholesterol levels were increased approximately 2-3 fold and the serum cholesterol level was $50-80 \%$ greater than that in the $20 \mathrm{C}$ group. However, no apparent effect of Equisetum arvense L. on serum and hepatic lipids was observed. In addition, there was no significant effect of Equisetum arvense L. on excreted lipids per total feces for 2 days, although total lipids per gram weight of feces at $4 \%$ Equisetum arvense L. was the lowest among the four experimental groups.

\section{Lipogenic enzyme activity}

Table 6 shows the activity of the NADPH-producing enzymes, malic enzyme and glucose-6-phosphate dehydrogenase. When rats were fed a cholesterol diet, the activities of glucose-6-phosphate dehydrogenase and malic enzyme were significantly decreased as compared to rats fed the $20 \%$ casein diet. However, no significant difference in the two enzyme activities was observed by the addition of Equisetum arvense $\mathrm{L}$. 
Table 5. Effects of Equisetum arvense L. and cholesterol on the content of glycogen, protein and lipids (Experiment 2).

\begin{tabular}{lcccc}
\hline & $20 \mathrm{C}$ & $20 \mathrm{CCS}$ & $20 \mathrm{CCS}+0.4 \mathrm{E}$ & $20 \mathrm{CCS}+4 \mathrm{E}$ \\
\hline Liver (mg/g liver) & & & & \\
$\quad$ Glycogen & $20.7 \pm 7.4$ & $13.7 \pm 5.3$ & $14.1 \pm 4.9$ & $14.8 \pm 1.7$ \\
$\quad$ Protein & $162 \pm 7$ & $157 \pm 26$ & $142 \pm 4$ & $141 \pm 4$ \\
Liver lipids ( $\mu \mathrm{mol} / \mathrm{g}$ liver) & & & & \\
$\quad$ Triglyceride & $27.3 \pm 4.9^{\mathrm{a}}$ & $83.0 \pm 10.2^{\mathrm{b}}$ & $88.1 \pm 13.9^{\mathrm{b}}$ & $70.1 \pm 9.4^{\mathrm{b}}$ \\
$\quad$ Phospholipid & $36.9 \pm 1.7^{\mathrm{a}}$ & $35.1 \pm 2.5^{\mathrm{a}, \mathrm{b}}$ & $33.5 \pm 0.9^{\mathrm{b}}$ & $36.7 \pm 1.2^{\mathrm{a}, \mathrm{b}}$ \\
$\quad$ Cholesterol & $8.7 \pm 1.1^{\mathrm{a}}$ & $22.1 \pm 0.6^{\mathrm{b}}$ & $22.5 \pm 0.2^{\mathrm{b}}$ & $21.2 \pm 0.3^{\mathrm{b}}$ \\
Serum lipids (mmol/L) & & & & \\
$\quad$ Triglyceride & $2.05 \pm 0.88$ & $1.31 \pm 0.16$ & $1.13 \pm 0.36$ & $1.26 \pm 0.15$ \\
$\quad$ Phospholipid & $1.80 \pm 0.36$ & $1.54 \pm 0.13$ & $1.46 \pm 0.17$ & $1.61 \pm 0.10$ \\
$\quad$ Cholesterol & $1.97 \pm 0.39^{\mathrm{a}}$ & $3.08 \pm 0.67^{\mathrm{b}}$ & $3.10 \pm 0.62^{\mathrm{b}}$ & $3.62 \pm 0.36^{\mathrm{b}}$ \\
Feces & & & \\
$\quad$ Total lipids (mg/g) & $200 \pm 23^{\mathrm{a}}$ & $209 \pm 10^{\mathrm{a}}$ & $223 \pm 26^{\mathrm{a}}$ & $132 \pm 7^{\mathrm{b}}$ \\
$\quad$ Total lipids $(\mathrm{mg} / 2$ days) & $187 \pm 28$ & $262 \pm 17$ & $263 \pm 60$ & $272 \pm 61$ \\
\hline
\end{tabular}

Values $(\mathrm{M} \pm \mathrm{SD}$ of five rats) in the same line not sharing a common superscript letter are significantly different at $p<0.05$.

Table 6. Effects of Equisetum arvense L. on the activity of hepatic malic enzyme and glucose-6-phosphate dehydrogenase (Experiment 2).

\begin{tabular}{lcc}
\hline Group & Malic enzyme & $\begin{array}{c}\text { Glucose-6-phosphate } \\
\text { dehydrogenase }\end{array}$ \\
\hline & & (nkat) \\
$20 \mathrm{C}$ & $558 \pm 132^{\mathrm{a}}$ & $833 \pm 248^{\mathrm{a}}$ \\
$20 \mathrm{CCS}$ & $273 \pm 72^{\mathrm{b}}$ & $278 \pm 57^{\mathrm{b}}$ \\
$20 \mathrm{CCS}+0.4 \mathrm{E}$ & $253 \pm 22^{\mathrm{b}}$ & $253 \pm 30^{\mathrm{b}}$ \\
$20 \mathrm{CCS}+4 \mathrm{E}$ & $248 \pm 70^{\mathrm{b}}$ & $208 \pm 53^{\mathrm{b}}$
\end{tabular}

Values $(\mathrm{M} \pm \mathrm{SD}$ of five rats) in the same column not sharing a common superscript letter are significantly different at $p<0.05$.

\section{Serum IgE level}

Figure 2 shows the serum IgE levels of rats fed Equisetum arvense L. on a cholesterol diet (Experiment 2). Although the enzyme-linked immunoassay was limited from 2 to $500 \mathrm{ng} / \mathrm{mL}$, the results obtained in this study were reproducible and reliable. Serum IgE levels in the four groups ranged from $3-20 \mathrm{ng} / \mathrm{mL}$ with the exception of an increase in the IgE level of one rat with severe dermatitis. However, those of another two rats with mild dermatitis were not different from the other three groups. 


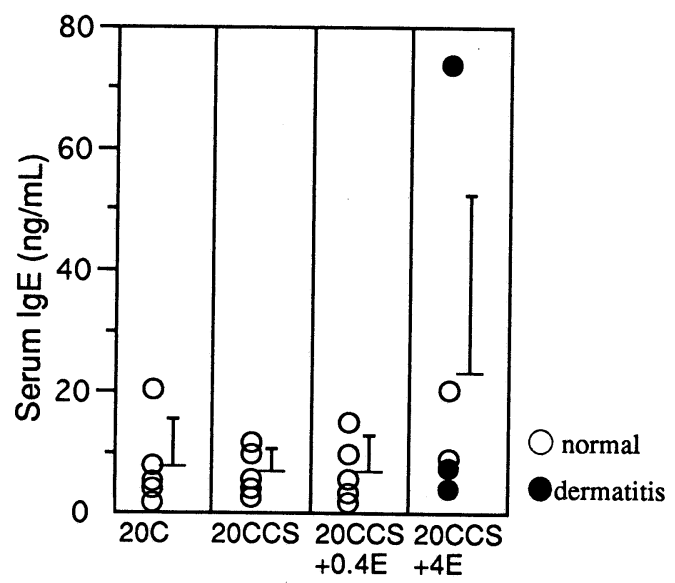

Fig. 2. Serum IgE levels on four different diets (Experiment 2). The vertical bars indicate the standard deviation of the mean of five rats. $\bigcirc$, rat with no dermatitis; rat with dermatitis.

\section{DISCUSSION}

In this study, the dietary addition of Equisetum arvense L. with or without a cholesterol diet did not significantly improve the level of serum and hepatic lipid components and lipogenic enzymes. The only significant effect of Equisetum arvense L. was the increased mass of excreted feces although the level of excreted lipids in the total feces was not significantly different. The increased mass of feces seemed to be due to the dietary fiber in Equisetum arvense L. Though each lipid component in the feces was not determined in this study, chlorophyll or its derivative was detected in the fecal lipids of rats fed $4 \%$ Equisetum arvense L., as determined by thin-layer chromatography (data not shown).

However, when rats were fed a cholesterol diet containing $4 \%$ Equisetum arvense L., about $65 \%$ developed dermatitis, and this dermatitis was not accompanied with any loss of body weight or food intake. This was reversed when Equisetum arvense L. was excluded from the diet. We conducted two additional experiments to confirm the occurrence of dermatitis caused by the inclusion of Equisetum arvense L. to a cholesterol diet for four weeks and six weeks, respectively. Six of 21 rats from the two experiments showed dermatitis on the neck and back; the incidence of dermatitis was about $20 \%$ and $30 \%$, respectively (data not shown). The occurrence of dermatitis in rat seems to depend on differences in the susceptibility of individual animals.

There are several possible explanations for the dermatitis caused by the addition of Equisetum arvense L. to a cholesterol diet. First, an antigen in Equisetum arvense L. causes an abnormal immunologic response such as a food allergy. A typical form of such an allergy is IgE-mediated type I hypersensitivity reaction to 
antigens present in food or food additives (18). But increased serum IgE levels were not observed in the rats with dermatitis except in one case. We also determined serum IgE levels in the additional experiment. The serum IgE levels of 16 normal rats and six dermatitis rats ranged from $2-10 \mathrm{ng} / \mathrm{mL}$ with the exception of $150 \mathrm{ng} / \mathrm{mL}$ in one normal rat, and no significant difference in the two groups was observed (data not shown). Furthermore, the incidence of dermatitis was approximately $20-65 \%$, and this is much higher than the $1-2 \%$ for food allergies in infants and children (19). However, this possibility cannot be eliminated completely because IgE antibody production is regulated tightly and the $\operatorname{IgE}$ response is turned off after a transient response (18). Second, diet containing Equisetum arvense L. causes a deficiency of vitamins such as vitamins $\mathrm{A}, \mathrm{B}_{2}, \mathrm{~B}_{6}$, pantothenic acid and nicotinic acid, which in turn causes dermatitis (20). It was reported that Equisetum arvense L. contains thiaminase (10) and antithiamine factor (11). This possibility is also improbable because neither weight gain, food intake nor food efficiency were changed by the intake of Equisetum arvense L. with or without a cholesterol diet. Third, when cholesterol was added to the experimental diet, cholate was usually added to help the absorption of cholesterol from intestine. Cholate in a cholesterol diet has a powerful detergent effect and promotes the absorption of not only cholesterol but also the lipophilic component(s) in Equisetum arvense L., and the absorbed component(s) or its metabolite damages the cell in the skin. It is reported that Equisetum arvense L. and Equisetum sporelings contain a flavonoid glucoside such as kaempherol and quercetin (21), a small amount of sterol such as $\beta$-sitosterol, campesterol and isofucosterol (22) and flavonoid such as herbacitrin and gossypitrin (23). In addition, it is also reported that the degradative products of chlorophyll such as photosensitive pheophorbide a or pyropheophorbide a in abalone $(24,25)$, alkaloid such as nicotine in the British species of Equisetum arvense L. (9) and horsetails (26) cause seborrhoiec dermatitis in rat and humans.

The exact mechanism responsible for the dermatitis caused by the addition of Equisetum arvense L. to a cholesterol diet is not known. Although the amount of Equisetum arvense L. consumed in green tea after a meal has no metabolic or toxic effect, an unfavorable reaction such as dermatitis may occur if large amounts of Equisetum arvense L. are taken together with a cholesterol-rich diet. Further investigations of dermatitis induced by Equisetum arvense L. are now under way.

We thank Drs. Mitsuko Okada, Takashi Yamashita and Yasuhiro Imakura at Naruto University of Education and Dr. Koji Yamada at Kyushu University for their helpful suggestions and comments.

\section{REFERENCES}

1) Terada S, Maeda Y, Masui T, Suzuki Y, Ina K. 1987. Comparison of caffeine and catechin components in infusion of various tea (green, oolong and black tea) and tea drinks. Nippon Shokuhin Kogyo Gakkaishi (J Jpn Soc Nutr Food Sci) 34: 20-27. 
2) Yoshino K, Hara Y, Sano M, Tomita I. 1994. Antioxidative effects of black tea theaflavins and thearubigin on lipid peroxidation of rat liver homogenates induced by tert-butyl hydroperoxide. Biol Pharm Bull 17: 146-149.

3) Sano M, Takenaka Y, Kojima R, Saito S, Tomita I, Katou M, Shibuya S. 1986. Effects of Pu-Erh tea on lipid metabolism in rats. Chem Pharm Bull 34: 221-228.

4) Muramatsu K, Fukuyo M, Hara Y. 1986. Effect of green tea catechins on plasma cholesterol level in cholestrol-fed rats. $J$ Nutr Sci Vitaminol 32: 613-622.

5) Kono S, Shinchi K, Ikeda N, Yanai F, Imanishi K. 1992. Green tea consumption and serum lipid profiles: a cross-sectional study in Northern Kyushu, Japan. Prev Med 21: $526-531$.

6) Ikeda I, Imasato Y, Sasaki E, Nakayama M, Nagao H, Takeo T, Yayabe F, Sugano M. 1992. Tea catechins decrease micellar solubility and intestinal absorption of cholesterol in rats. Biochim Biophys Acta 1127: 141-146.

7) Imai K, Nakachi K. 1995. Cross sectional study of effects of drinking green tea on cardiovascular and liver disease. $\mathrm{Br}$ Med J 310: 693-696.

8) Evans ETR, Evans WC, Roberts HE. 1951. Studies on bracken poisoning in the horse. Br Vet J 107: 364-371.

9) Phillipson JD, Melville C. 1960. An investigation of the alkaloids of some British species of Equisetum. J Pharm Pharmacol 12: 506-508.

10) Henderson JA, Evans EV, McIntosh RA. 1952. The antithiamine action of Equisetum. $J$ Am Vet Med Ass 120: 375-378.

11) Nakabayashi T. 1957. Studies on the thermostable antithiamine factor. Part II. Thiamine decomposing substances of horsetail (the basidium of Equisetum arvense L.). Vitamins (Japan), 12: 20-24.

12) Maeda H, Fujiwara M, Fujita K, Fukuda N. 1996. Hypertriglyceridemia and fatty liver of fasting rats after administration of emeriamine. J Nutr Sci Vitaminol 42: 111-120.

13) Folch J, Lees M, Sloane-Stanley GH. 1957. A simple method for the isolation and purification of total lipids from animal tissues. $J$ Biol Chem 226: 497-509.

14) Johnson JA, Fusaro RM. 1966. The quantitative enzymic determination of animal liver glycogen. Anal Biochem 15: 140-149.

15) Gornall AG, Bardawill CS, David MM. 1949. Determination of serum proteins by means of the biuret reaction. $J$ Biol Chem 177: 751-766.

16) Lowry OH, Rosebrough NJ, Farr AL, Randall RJ. 1951. Protein measurement with the folin phenol reagent. $J$ Biol Chem 193: 265-275.

17) Duncan DB. 1955. Multiple range and multiple F tests. Biometrics 11: 1-42.

18) Chowdhury BA. 1995. Regulation of IgE production and other immunopathogenetic mechanisms. Clin Rev Allergy Immunol 13: 315-328.

19) Bock SA, Sampson HA. 1994. Food allergy in infancy. Pediatr Clin N Am 41: 1047-1067.

20) Koike G, Fukuba H. 1984. Skin. In: Eiyougakujiten (Koike G, Fukuba H, eds), p. 333. Asakurashoten, Tokyo.

21) Saleh NAM, Majak W, Towers GHN. 1972. Flavonoids of Equisetum species. Phytochemistry 11: 1095-1099.

22) D'Agostino M, Dini A, Pizza C, Senatore F, Aquino R. 1984. Sterols from Equisetum arvense. Boll Soc Ital Biol Sper 60: 2241-2245.

23) Iio M, Shirahata S, Ohta N. 1990. Effects of herbacitrin, a flavonoid, on the growth of normal and transformed serum-free mouse embryo cells. Agric Biol Chem 54: 2743-2744.

24) Clare NT. 1955. Photosensitization in animals. Adv Vet Sci 2: 182-211. 
25) Tsutsumi J, Hashimoto Y. 1964. Isolation of pyropheophorbide a as a photodynamic pigment from the liver of abalone, Haliotis discus hannai. Agric Biol Chem 28: 467-470.

26) Sudan BJL. 1985. Seborrhoeic dermatitis induced by nicotine of horsetails (Equisetum arvense L.). Contact Dermatitis 13: 201-202. 